\title{
A Theoretical Vacuum: European Integration and Historical Research Today
}

\author{
John R. GILLINGHAM
}

In the lead article of this journal's inaugural issue, "Allegiance. The Past and the Future", which was published over a decade ago, Alan S. Milward, a giant in the study of the political economy of Europe since 1945, proclaimed the intellectual liberation of historical integration research from bondage to American social science and, at the same time, heralded "the beginning of a new period [...] where history has its own theories and a research agenda which derives from them". Nothing of real importance has, sadly, ever come of this bold initiative. Now, as then, most historians of European integration resemble, in Milward's harsh judgment, "children on a crowded beach, building separate small sand castles", lacking theoretical foundations or structural support, "all of which look very vulnerable to the incoming tide". ${ }^{1}$

Integration history, a quasi-official field of study, remains bound by a conventional wisdom that posits the inevitable development of the EU into a federal European state, an end which - as now abundantly evident - is neither likely or desirable. Without a new historical theory of integration, it will be impossible to determine how the integration process has advanced, or failed to do so, and where it has gone wrong as well as right. In the absence of theory, historical literature on the subject will either drift off into irrelevance or be swept away in a tidal wave of change by history itself.

Historical integration theory still remains, in the words of the British Marxist Perry Anderson, "under the sign of the interim". Because it has not driven, or even much influenced, the research agenda, the relevant literature continues to be dominated, according to Johnny Laursen, by "histoire événementielle, closely related to its near cousin, diplomatic history". ${ }^{2}$ Research remains in its infancy. The existing literature deals chiefly with origins and neglects institutions; few descriptions of how they actually function, either alone or together, are to be found. Historians have also largely left the economics of integration to others. The study of the last thirty years - surely the most consequential in the EU's history - has furthermore barely begun, and the significance these crucial decades for the interpretation of earlier periods remains unexamined. The Big Questions overhanging the future of the EU are still unaddressed. The stale air of antiquarianism overhangs the historical field.

1. A.S. MILWARD, Allegiance: The Past and the Future, in: Journal of European Integration History, 1(1995), pp.7-19.

2. P. ANDERSON, Under the Sign of the Interim, in: P. GOWAN, P. ANDERSON (eds.), The Question of Europe, Verso Books, London, 1997, pp.51-76; J. LAURSEN, Towards a Supranational History, in: Journal of European Integration History, 1(2002), p.5. 
Milward is himself partly to blame for the vacuum of theory. His own take on the matter, presented in the JEIH kick-off article and elaborated upon in his massive work, The European Rescue of the Nation-State, will not withstand serious scrutiny. ${ }^{3}$ Milward cannot, however, be held solely accountable for the fact that no one from the guild of official integration historians has yet designed a better mousetrap. The guild and its house journal are plagued by parochialism - the predictable product of captive scholarship. What else should one expect when the EU is both sponsor and subject? Should one really expect the JEIH's editorial board of nine Jean Monnet Chairs (of twelve total) to encourage independent, not to mention critical, analysis? Why bite the feeding hand? ${ }^{4}$

The opening words of Milward's inaugural article allude to, but hardly resolve, the $U r$-problem, which cripples historical research up to the present: the equation of "integration" with the single set of institutions headquartered in Brussels and today known as the European Union..$^{5}$ The assumption of identity strips other trends and tendencies which have contributed to the integration process of their right to historical acknowledgement and lumps them under a single heading; credits the EU undeservedly as the sole source of change; overlooks the importance of context as parameter for policy-making; and, finally, neglects impacts. Thus process and policy are conflated and unintended consequences get ascribed merely to mistakes or oversights of human agents rather than to the operation of factors beyond their control. The result is a one-dimensional historical literature which often confuses official reality with the thing itself, is overspecialized, mistakes the forest for the trees, and has had little impact either outside its own narrow field of scholarship or with either policy-makers or publics. Now that serious criticism is needed to set the EU aright, historians can offer little guidance.

\section{Milwardian Integration Theory}

Although surely better than nothing, the one major attempt yet made to lend coherence to historical writing in the integration field wrong-footed it and misdirected research. The theoretical claims Milward makes in "Allegiance" are both sweeping and muddled. Although pointing to the need for a synthesis of the four existing approaches to the European integration process, he leaves little doubt that only his own, demonstrably idiosyncratic, position should really count in the overall blend. The first such approach mentioned by Milward actually coincides with the standard, shopworn quasi-diplomatic tack cited by Laursen as the historian's present-day stock-in-trade; it leads nowhere, in Milward's view. The second - which he dismisses as naïve, outmoded, and hagiographical - emphasizes

3. A.S. MILWARD, The European Rescue of the Nation-State, Routledge, London, 1993.

4. Critical annotation by the editorial board of JEIH: Except for the first six issues (three first years), the Journal of European Integration History doesn't receive any funds from Brussels!

5. A.S. MILWARD, Allegiance ..., op.cit., p.7. 
the importance of altruism as a motive as well as its obverse side, the rejection of traditional national diplomacy, which, purportedly, led to the two world wars. A third approach, a promising one, which he also brushes off, views Europe's integration since World War II as an intermediate step towards the restoration of an open world market. That leaves only the final theory, Milward's very own, which holds "that the process of integration was deliberately conceived and developed to preserve the nation-state by supporting a range of new social and economic policies whose very purpose was the resurrection of the nation-state after its collapse between 1929 and 1945". ${ }^{6}$

This is fanciful. Little evidence of Milward's grand design has ever turned up. And the propositions are simply untenable that "the Union exists because it has been a response by national governments to popular demand" and that it "buttressed the nation-state in the pursuit of income, welfare, family security and employment". 7 The efficacy of his theory furthermore rests on the assumption that Brussels can, and does, render crucial services more efficiently than possible at the national, or international, level - on so-called output legitimacy. This is easy to posit but hard to demonstrate.

Prior to the Davignon Plan of the late 1970's for the rescue of the steel industry, the only major operational program of the European Economic Community (the forerunner of the EU) was the almost universally condemned Common Agricultural Policy (CAP), an economically wasteful and unnecessary program though still very much alive - which was originally adopted primarily as a political payoff to France. For its part, EU social policy has always been mainly chatter, and the same was, and remains, true of security policy. A case can be made be made in the financial field, to be sure, for the seriousness of the Werner Plan for a currency union (1969) but until the monetary regime change of the 1970s, the EU was little more than a paper project; it was hardly, as Milward admitted, "the locus of power and decision-making". ${ }^{8}$ Since then, the EU's record on "output legitimacy" has, at best, been decidedly mixed - the technocratic rationale is barely credible - and that on political responsiveness ("input legitimacy") obviously poor. The democratic deficit is gaping.

Confident in 1995, the year JEIH began publication, that his theory could be proven, Milward set as Item Number One on his future research agenda for integration history the concept of "Allegiance," as indicated in the title of his article. He apparently coined the term as a surrogate for patriotism (a word somewhat hard to swallow) in the expectation that something like it could develop at the EU level. The concept is confusing. On the one hand he compares it to $19^{\text {th }}$ century patriotism, but on the other hand insists on both its qualitative difference and its "secondary" quality. Apparently baffled, he concludes merely with queries:

6. Ibid., pp. $11 \mathrm{f}$.

7. A.S. MILWARD, The Social Basis of Monetary Union, in: P. GOWAN, P. ANDERSON (eds.), op.cit., pp.152 and 160.

8. A.S. MILWARD, Allegiance ..., op.cit., p.12. 
"What is 'European' allegiance? Is it primarily cultural, economic, idealistically political, realistically political, or simply born from fear or prejudice? And how has it changed since $1945^{\prime \prime}$ ?

Better to have asked whether such a phantom ever existed! The two botched constitutional referenda cast serious doubt on the purported popularity of the EU. The current intense, top-level effort to prevent however and wherever possible a rerun of the previous scenario - public rejection of what has now been re-named the "Reform Treaty" - merely increases public suspicion. In a nutshell: the European Union has not developed as envisioned by its ambitious champions, and is indeed badly foundering. The tide, forewarned by Milward, has begun to rush in. Sound theory will be needed to prevent the little sand castles - many of them actually quite nice - from being washed away. How should one begin to build it?

\section{A New Integration Theory?}

The present European Union grew out of a deep-felt desire to heal the wounds of a nationalistic past, a need to capture economies of scale, a hope for protection from the whims of superpower politics, a wish to run one's own show, and from a lack of better alternatives as well as the dream of a better future. The main accomplishments of the EU are evident: it has ended the economic division of Europe into national markets, defused conflict between neighbours, promoted democracy and good government, and restored the confidence of Europeans in the values and vitality of their civilization. Yet the days of triumphalism are over. The EU is neither on a one-way track headed for federal union (as professed by its champions) nor something unique in history and therefore not subject to the usual performance criteria (as claimed by its apologists) but an institution which increasingly resembles other international organizations, past and present, and should be compared to them. The relevant model may not be the Holy Roman Empire, as provocatively suggested recently by Jan Zielonka and as echoed by none other than the tin-eared Commission president José Manuel Barroso, but it is also certainly not the Westphalian nation-state writ large implicit in Euro-federalist thinking, the idea which drives and is reflected in most EU scholarship. ${ }^{10}$

A viable theory of European integration must first face certain unpleasant realities. The EU is no closer to having its own armed forces today than it was over fifty years ago when the European Defense Community was first proposed. The European Social Model is still mere political rhetoric. The ruinous Common Agricultural Policy cannot be eliminated or even tampered with until 2013. The long list of policy failures must also include the several Framework, as well as many targeted acronym programs, for research and development, as well as their

9. Ibid., pp.147 f., 17.

10. J. ZIELONKA, Europe as Empire: The Nature of the Enlarged European Union, Oxford University Press, Oxford, 2006. 
high-tech successors, Galileo and the Airbus 380. The grim list should also include "big projects" like the Lisbon Agenda and, almost surely, the ambitious carbon emissions scheme. The gains of recent years - competition and internal market policy and enlargement - have also been stopped in their tracks, are slipping away, or being reversed by so-called economic patriotism. Administrative reform appears to be all but impossible, red tape has become asphyxiating, and representative and responsive governance seems increasingly remote. The EU is powerless in the face of a resurgent Russia and unequipped to deal with the challenges of large-scale labour mobility. European institutions vitiate national democracy and slow economic growth.

Far from being upward and steady, the EU's growth trajectory has been a succession of zigs, zags - and lags. The pattern reflects the chronic tension between two quite different conceptions of what European integration is and should become; it is manifest in ideas, policies, and institutions. The first of these poles is, of course, the familiar Monnetist/Delors view that its goal is a political and economic union and its method the exercise of political and administrative authority from the top down through powerful, centralized institutions. This is the only approach to integration with which most guild historians are familiar.

The second of these poles, less well-known but no less important in the history of the subject, is the view that eliminating marketplace distortions in favour of competition will stimulate growth and result in closer union. Frederick Hayek is the name most closely associated with this approach. On the eve of the Second World War, Hayek explained in a seminal article how, once heterogeneous populations join together in an interstate federation, the absence of trade barriers would prevent an identification of economic interests between nations and peoples, thereby limiting opportunities for market-distorting policies. The spontaneous order of the market could thus eventually develop unimpeded. Although Ludwig Erhard, and his economic team, introduced Hayekian approaches into the integration process, only after the collapse of the Bretton Woods system - which had buffered the mixed economy welfare states of Europe from the influence of world markets - did the process of spontaneous order really begin to take hold and make itself felt in the integration process.

Change, it soon became clear, took place more easily by means of "negative" integration - that is, by applying "thou-shalt-not rules" to economic activity rather than "positive integration" - the creation of new institutions to overcome "market failure". While "state-builders" and agents of "positive integration" like Jean Monnet and Jacques Delors still occupy centre stage in integration discourse, "marketeers" of the Hayekian persuasion produce more solid results, as evident not only in EU success stories like the single external tariff and the Single European Act, but in spillovers from the market place, which generate new wealth, fresh ideas, and dynamic social change. ${ }^{11}$ Historians must learn how to take them into account.

11. J. GILLINGHAM, European Integration, 1950-2003: Superstate or New Market Economy, Cambridge University Press, Cambridge/New York, 2003, pp.xii-xv. 
Verdicts on the results naturally vary. In Perry Anderson's critical words,

"[w]hat was originally the least prominent strand in the weave of European integration had become the dominant pattern. Federalism stymied, inter-governmentalism corroded, what had emerged was neither the rudiments of a European democracy controlled by its citizens, nor the formation of a European directory guided by its powers, but a vast zone of increasingly unbound market exchange, much closer to a European "catallaxy" as Hayek had conceived it". ${ }^{12}$

An alternative interpretation of the process would credit it for stimulating growth, reducing over-centralization, restoring political authority to electorates, eliminating bureaucratic inefficiency, reducing oligopoly and the state-sanctioned entrenchment of political power, and strengthening the judicial system. The EU emerging from such a process would be limited in its exercise of statutory power, confederal as opposed to federal, based on contract, subject to public scrutiny, answerable to the member-states, and empowered only when able to function more efficiently than lower levels of authority. ${ }^{13}$

Regardless of one's judgments on market-driven change or, more broadly, on neo-liberalism, to limit the study of integration to the workings of official policies and institutions is to miss much of what has gone on. Modernization should be the yardstick of integration success, and what sets it in motion ought to be explored nationally and internationally, as well as at the European level. In brief, the integration process must be conceived much more broadly than at present. It can be thought of as the outcome of a three-level interdependence game able to begin or end at any point - national, international, or European. Context is critical to the unfolding of the process, which may well have unintended consequences. Thus by enabling currencies to move more freely against one another then previously, the collapse of the Bretton Woods system set up at the end of World War II to peg exchange rates to the dollar provided the solvent needed to erode the national buffers that shielded the mixed economy welfare state from the exogenous pressures of the international market. Security ceded priority to growth as a policy priority, and economic survival would in the future depend upon competitiveness. The stage was now not only set for the present era of globalization, but for the adoption of the Single European Act. It would transform the EU from what, for the most part, had been a paper project into a power to be reckoned with. ${ }^{14}$

Therewith, it also injected the EU, an elitist project, into the public forum. The peoples of Europe would thus inadvertently become players in a game whose rules did not originally include them. The more they learned about Brussels, however, the less they liked what they saw. The EU is better considered a community of interest held together by political deals, than a community of sentiment held together by shared loyalties.

12. P. ANDERSON, Depicting Europe, in: London Review of Books, 20 September 2007, pp.23-41.

13. J. GILLINGHAM, Design for a New Europe, Cambridge University Press, Cambridge/New York, 2006, in passim.

14. Ibid., pp.63-70. 
A European demos will not develop until the central EU institutions cease being dysfunctional. Only then can they also eventually become representative - and not an organizational nightmare. The suggestion that the Brussels apparat somehow reflects the checks and balances system of American federalism would set James Madison spinning in his grave. No one knows where power rests, because jurisdiction is divided in weird ways, deal-making is exceptionally difficult, many discordant voices pronounce on policy, and governance, shrouded in secrecy, is virtually opaque. For its part, the pseudo-executive, the Commission, is bureaucratic, corrupt, and resistant to reform. The bloated Parliament is overpaid and under-worked, a talk shop, whose search for relevance produces demagogy. Real power remains in the hands of the member states, which have generated a parallel bureaucracy, which duplicates the work of the Commission. The costs of over-regulation are prohibitive and weigh heavily on economic growth. Brussels' only real lever of power is European law, something which remains subject to the challenges of national supreme courts. ${ }^{15}$

Yet, because the enforcement of Commission directive and regulations rests with the individual member-states, Brussels can do little to curtail non-compliance, the extent of which is vast though also still largely unknown. A conspiracy of silence prevails. So does a powerful undercurrent of public mistrust. Adding to the problem of accountability, the directing board of the European Central Bank, which runs "Euroland" (and therefore is actually more powerful than even the EU), answers to no higher institution or body. It also seriously undercuts fiscal as well as monetary sovereignty, and thereby moreover the authority needed by national governments to come to grips with the two most severe economic problems of the day, the costly welfare state and inflexible labour markets. The ECB's one-size-fits-all approach also stifles economic growth. ${ }^{16}$

An historical theory of the origins of this situation would be timely. Just as the Empty Chairs Crisis of the late-1960's discredited "functionalism", the successive setbacks encountered by the European Union since the Maastricht Conference (1993) have poured cold water on its only real successor, Andrew Moravscik's "liberal governmentalism". The theory posits that the integration driver has been successive, increasingly ambitious bargains arrived at by optimally-negotiating member states. It makes no provision for policy failure. ${ }^{17}$ Political science also now operates in something of a vacuum.

No single theory can at this point purport to "explain" the history of European integration satisfactorily. A first step in the right direction would be to broaden the research agenda. The "thirty year rule" governing access to most public records should no longer be allowed to pose an insuperable barrier to historical inquiry into the recent past of the EU. Mere mention of the Internet should underscore,

15. J. GILLINGHAM, Design ..., op.cit., passim.

16. Ibid., pp. 55-106.

17. A. MORAVCSIK, The Choice for Europe: Social Purpose and State Power from Messina to Maastricht, Cornell University Press, Ithaca, 1998. 
secondly, the existence of a huge untapped treasure trove, which, when mined properly, can provide immense economies in information retrieval. Historians can also no longer afford to overlook the rich and varied literature of Political Science and International Relations, which includes seemingly endless numbers of specialized studies on the workings of EU and EU-related institutions and covers industry, finance, law, and research and development - to name only a few of the many large gaps in the historical literature - as well as theory. Nor should Economics continue to be largely ignored in an institutional tradition inspired by Monnet, who looked to experts, rather than politicians, for ways to reconcile peoples.

Above all, historians should examine what has gone wrong, as well as what has gone right, with the European Union. Drawing comparisons and considering alternatives must figure in future studies. Only then will it be possible to determine what the EU of tomorrow can and should attempt to accomplish. If the history of the EU is not reexamined, the sand castles, once washed away, will be forgotten altogether. 


\title{
Informal Politics of Integration: Christian Democratic and Transatlantic Networks in the Creation of ECSC core Europe
}

\author{
Wolfram KAISER and Brigitte LEUCHT
}

The historiography of the origins of the European Union (EU) has two main weaknesses. It is too state-centric and fails to conceptualise the embedded nature of ideas and their role in the creation and evolution of an integrated 'core Europe' after World War II. With the opening up of the archives of national governments and supranational institutions, research on the contemporary history of the EU has steadily moved on into the 1970s. We argue, however, that it is crucial to revisit the early postwar period to develop a more sophisticated notion and historical narrative of the formation of the supranational core Europe of the European Coal and Steel Community (ECSC) of six founding member-states. Sectoral integration in coal and steel did not lead directly to horizontal integration in the customs union of the European Economic Community (EEC). It created important path dependencies concerning some structural characteristics and policy solutions, however, especially the (self-) exclusion of Britain, the functional use of economic integration with long-term political as well as economic objectives, the introduction of the supranational principle and antitrust competition legislation.

Historians have predominately conceived of the formation of the ECSC as the result of interstate bargaining of 'national interests' by governments as cohesive, purposeful actors. ${ }^{1}$ Diplomatic historical accounts have been shaped by underlying 'realist' assumptions about the definition of such interests by autonomous foreign and European policy-making elites. In the case of France, such national interests included the control of Germany through integration and securing a dominant political leadership role for France, and in the case of Germany, regaining national sovereignty and achieving the integration of the newly created Federal Republic of Germany in Western Europe and the Atlantic Alliance on the basis of equality. The notion of American 'influence' in the historiography of transatlantic relations after 1945 similarly derives from the assumption of European state actors' interests in the involvement of the United States as 'ultimate arbiter'" in Western European politics. ${ }^{3}$ In this perspective, the United States primarily had powerful political, economic and military resources to secure for itself a dominant position in the

1. As an introduction to EU historiography see W. KAISER, From State to Society? The Historiography of European Integration, in: M. CINI, A.K. BOURNE (eds.), Palgrave Advances in European Union Studies, Palgrave, Basingstoke, 2006, pp.190-208.

2. G. LUNDESTAD, The United States and Western Europe since 1945. From 'Empire by Integration' to 'Transatlantic Drift', Oxford University Press, Oxford, 2003 [1998].

3. See for example K. SCHWABE, 'Ein Akt konstruktiver Staatskunst' - die USA und die Anfänge des Schuman-Plans, in: Idem. (ed.), Die Anfänge des Schuman Plans 1950/51, Nomos, Baden-Baden, 1988, pp.211-239. 